\title{
Wakaf Uang dan Pengaruhnya terhadap Program Pengentasan Kemiskinan di Indonesia
}

\author{
M. Nur Rianto Al Arif \\ Fakultas Syariah dan Hukum UIN Syarif Hidayatullah Jakarta \\ agif08@gmail.com
}

\begin{abstract}
Cash waqf has played a significant role in economics as one of the new Islamic fiscal instruments. Cash waqf has two functions. First, it functions as a facility for the purpose of worship and secondly, it constitutes means as to achieve social welfare. The return of cash waqf management can be used as an instrument for poverty alleviation program through social security system. As a social security system, cash waqf will contribute to the government's alleviation program which focuses on community empowerment. This paper discusses the role of cash waqf in alleviating poverty which recently has become government program. It observes how the income of the cash waqf is distributed and how it gives an impact on the poverty alleviation in Indonesia. Deploying bibliographical and empirical investigation, this paper argues that the cash waqf has significant role in financial empowerment of the society.
\end{abstract}

\begin{abstract}
Abstrak
Wakaf uang telah memainkan peranan yang penting sebagai salah satu instrumen fiskal Islam yang baru di dalam perekonomian. Wakaf uang memiliki dua fungsi sebagai sarana ibadah dan pencapaian kesejahteraan sosial. Pengembalian dari pengelolaan wakaf uang dapat dipergunakan sebagai instrumen dalam program pengentasan kemiskinan melalui sistem jaminan sosial. Sistem jaminan sosial menggunakan wakaf uang akan dapat membantu program pengentasan kemiskinan yang dilakukan pemerintah melalui program pemberdayaan masyarakat. Makalah ini mendiskusikan tentang peran wakaf uang dalam upaya pengentasan kemiskinan di Indonesia yang belakangan ini menjadi program utama pemerintah. Makalah ini mencoba mengupas tentang bagaimana pemasukan wakaf uang didistribusikan dan dimanfaatkan dan bagaimana wakaf tersebut mampu memberikan dampak baik bagi upaya pengentasan kemiskinan. Mempergunakan metode kajian pustaka dan penelitian lapangan, makalah ini menegaskan bahwa wakaf uang mempunyai peran yang penting dalam upaya pengentasan kemiskinan.
\end{abstract}


Kata Kunci: wakaf tunai, program pengentasan kemiskinan, sistem jaminan sosial

\section{Pendahuluan}

Saat ini telah terjadi perubahan yang signifikan atas pemahaman dan pemberdayaan harta wakaf di masyarakat, pada awalnya praktek wakaf lebih banyak dikembangkan pada sarana ibadah, sarana pendidikan, sarana kesehatan, dan manfaat sosial lainnya menjadi suatu wakaf produktif termasuk salah satunya dalam bentuk wakaf uang. Perluasan dari pemahaman dan pemberdayaan harta wakaf menjadi suatu hal yang penting terutama jika dikaitkan dengan konsep pengembangan wakaf produktif yang bertujuan untuk kepentingan sosial kemasyarakatan.

Wakaf produktif memiliki dua visi sekaligus: ${ }^{1}$ menghancurkan strukturstruktur sosial yang timpang dan menyediakan lahan subur untuk mensejahterakan umat Islam. Visi ini secara langsung digapai ketika totalitas diabdikan untuk bentuk-bentuk wakaf produktif yang selanjutnya diteruskan dengan langkah-langkah taktis yang mengarah pada capaian tersebut. Langkah taktis, sebagai derivasi dari filosofi disyariatkannya wakaf produktif dimana lebih berupaya teknis-teknis pelaksanaan wakaf produktif.

Penerapan wakaf uang sebagai salah satu bentuk wakaf produktif pada masa sekarang akan mempunyai keunggulan yang lebih besar dari wakaf tradisional, yaitu benda bergerak atau tidak bergerak. Identik di masyarakat apabila dikatakan harta wakaf, maka akan langsung dihubungkan dengan sekolah, rumah sakit dan atau kuburan. Secara umum, wakaf benda bergerak atau tidak bergerak hanya dapat dilakukan oleh orang yang memiliki harta lebih. Hal inilah yang menyebabkan kekayaan wakaf di Indonesia masih sedikit. Selain karena jumlah harta wakaf yang masih sedikit, pengelolaannya pun masih belum menerapkan manajemen modern. Sedangkan wakaf uang dapat dilakukan banyak orang, meskipun tidak kaya. Seseorang dapat berwakaf uang sebesar Rp. 100.000,-.

Wakaf uang tersebut dapat dihimpun dalam sebuah wadah, sehingga menjadi modal usaha yang besar. Dana wakaf uang yang terkumpul tersebut dapat dikelola secara produktif dengan lembaga pengelola yang memiliki kompetensi dan kapabilitas serta mampu bekerja secara profesional. Pengoptimalan sumber-sumber keuangan Islam termasuk wakaf uang sebagai salah satu sub-sistem yang dapat mendukung program pemberdayaan

\footnotetext{
${ }^{1}$ Abdurrahman Kasdi, "Pemberdayaan Wakaf Produktif Untuk Keadilan Sosial dan Kesejahteraan Umat (Optimalisasi Potensi Wakaf Produktif di Indonesia)”, Jurnal Asy-Syir'ah, Vol. 44, No. II, (2010): 796.
} 
masyarakat yang dilaksanakan oleh pemerintah terkait dengan pengentasan permasalahan kemiskinan yang terdapat di masyarakat terutama di negara berkembang seperti Indonesia.

Dukungan dari sub-sistem selain pemerintah sangat dibutuhkan agar manfaat pemberdayaan masyarakat dapat semakin berdayaguna dalam meningkatkan kemaslahatan masyarakat, karena seluruh program pengentasan kemiskinan yang telah dilaksanakan oleh pemerintah dengan tujuan untuk memberdayakan masyarakat masih belum mampu memperlihatkan hasil yang signifikan di masyarakat. Hal ini menandakan bahwa program pemberdayaan masyarakat masih membutuhkan dukungan dari sub-sistem lain.

Melalui metode penelitian kepustakaan dan observasi, artikel ini akan menyoroti kemiskinan sebagai permasalahan yang selalu ada di setiap negara baik dalam bentuk kemiskinan yang sifatnya absolut maupun kemiskinan relatif. Upaya-upaya penyelesaian dari masalah kemiskinan ini juga akan didiskusikan dalam artikel ini tanpa mengesampingkan pengaruh yang akan berdampak pada aktivitas perekonomian.

\section{Definisi Wakaf}

Dalam peristilahan shara' secara umum, ${ }^{2}$ wakaf adalah sejenis pemberian yang pelaksanaannya dilakukan dengan jalan menahan (pemilikan) asal (tahbis al aṣli), lalu menjadikan manfaatnya berlaku umum. Yang dimaksud tahbis al aṣli ialah menahan barang yang diwakafkan itu agar tidak diwariskan, dijual, dihibahkan, digadaikan, disewakan dan sejenisnya. Sedangkan cara pemanfaatannya adalah menggunakan sesuai dengan kehendak wāqif tanpa imbalan. Menurut Imam Syafi'i dan Ahmad bin Hambal bahwa wakaf adalah melepaskan harta yang diwakafkan dari kepemilikian wäqif, setelah sempurna prosedur perwakafan. Wäqif tidak boleh melakukan apa saja terhadap harta yang diwakafkan, seperti perlakuan pemilik dengan cara memindahkan kepemilikannya kepada yang lain, baik dengan tukar menukar atau tidak. Jika wakif wafat, harta yang diwakafkan tersebut tidak dapat diwariskan. ${ }^{3}$

Wakaf didefinisikan sebagai perbuatan hukum wāqif untuk memisahkan dan/atau menyerahkan sebagian harta benda miliknya untuk dimanfaatkan selamanya atau untuk jangka waktu tertentu sesuai dengan kepentingannya guna keperluan ibadah dan/atau kesejahteraan umum menurut syariah. ${ }^{4}$

${ }^{2}$ M. Cholil Nafis, "Wakaf Uang Untuk Jaminan Sosial”, Jurnal Al-Awqaf, Vol. II, No. 2, April 2009.

${ }^{3}$ M. Syakir Sula, "Implementasi Wakaf dalam Instrumen Asuransi Syariah". Jurnal AlAwqaf, Vol. II, No. 2, April 2009. 2006.

${ }^{4}$ Undang-undang No. 41 tahun 2004 tentang wakaf dan Peraturan Pemerintah no. 42 tahun 
Komisi Fatwa Majelis Ulama Indonesia dalam putusan fatwanya tentang wakaf tunai memberikan pengertian bahwa "wakaf adalah perbuatan hukum seseorang atau kelompok orang atau badan hukum yang memisahkan sebagian dari benda miliknya guna kepentingan ibadat atau keperluan umum lainnya sesuai dengan ajaran Islam" dan "benda wakaf adalah segala benda, baik bergerak atau tidak bergerak, yang memiliki daya tahan yang tidak hanya sekali pakai dan bernilai menurut ajaran Islam. ${ }^{\text {'5 }}$

Wakaf telah menjadi salah satu instrument fiskal Islam yang telah ada semenjak awal kedatangan Islam. Fakta sejarah memperlihatkan bahwa wakaf telah menunjukkan berbagai peran penting dalam mengembangkan berbagai kegiatan sosial, ekonomi, pendidikan dan kebudayaan. Wakaf harus mampu berperan efektif dalam membangun umat, agar mampu mengurangi ketergantungan pendanaan dari pemerintah. Wakaf terbukti mampu menjadi instrumen jaminan sosial dalam pemberdayaan masyarakat.

Berdasarkan definisi wakaf yang terdapat dalam Undang-undang, wakaf pada masa sekarang ini mengakomodir berbagai macam harta benda wakaf termasuk adalah wakaf uang. Secara spesifik, undang-undang tersebut memuat bagian tentang wakaf uang, dimana dalam pasal 28 sampai pasal 31 ialah wakaf uang harus disetor melalui Lembaga Keuangan Syariah (LKS) yang telah ditetapkan oleh Menteri Agama RI. Wakaf uang harus dibuktikan dengan sertifikat.

\section{Potensi Wakaf Uang}

Dalam Peraturan Badan Wakaf Indonesia No. 01 tahun 2009 tentang Pedoman Pengelolaan dan Pengembangan Harta Benda Wakaf Bergerak berupa Uang, sertifikat dapat diberikan kepada wakafi yang telah mewakafkan uangnya paling sedikit Rp 1.000 .000 (satu juta rupiah) dengan menyertakan asal-usul uang dan identitas lengkap wāqif nya.

Jumlah umat Islam yang terbesar di dunia terutama di Indonesia merupaka aset terbesar untuk penghimpunan dan pengembangan wakaf uang. Jika wakaf uang dapat diimplementasikan maka akan terdapat dana potensial yang dapat dipergunakan bagi kemaslahatan umat. Berdasarkan asumsi Cholil Nafis, ${ }^{6}$ jika 20 juta umat Islam Indonesia mau mengumpulkan wakaf uang senilai Rp 100 ribu setiap bulan, maka dana yang terkumpul berjumlah Rp 24 triliun setiap tahun. Jika 50 juta orang yang berwakaf, maka setiap tahun akan terkumpul dana wakaf sebesar Rp 60 triliun. Jika saja terdapat 1 juta umat Muslim yang

\footnotetext{
${ }^{5}$ Kompilasi Hukum Islam di Indonesia, Buku II, Bab I, Pasal 215, (1) dan (4). April 2009.

${ }^{6}$ Cholil Nafis, "Wakaf Uang Untuk Jaminan Sosial", Jurnal Al-Awqaf, Vol. II, Nomor 2,
} 
mewakafkan dananya sebesar Rp 100.000 per bulan, maka akan diperoleh pengumpulan dana wakaf sebesar Rp 100 miliar setiap bulannya (Rp 1,2 triliun per tahun).

Menurut Mustafa Edwin Nasution ${ }^{7}$ tentang potensi wakaf di Indonesia dengan jumlah umat Muslim yang dermawan diperkirakan sebesar 10 juta jiwa dengan rata-rata penghasilan $\mathrm{Rp} .500 .000$ hingga Rp. 10.000.000, maka paling tidak akan terkumpul dana sekitar 3 triliun per tahun dari dana wakaf seperti perhitungan tabel berikut:

\begin{tabular}{|c|c|c|c|c|}
\hline $\begin{array}{c}\text { Tingkat } \\
\text { penghasilan/bulan }\end{array}$ & $\begin{array}{l}\text { Jumlah } \\
\text { Muslim }\end{array}$ & $\begin{array}{c}\text { Besar } \\
\text { wakaf/bulan }\end{array}$ & $\begin{array}{c}\text { Potensi wakaf } \\
\text { uang/ bulan }\end{array}$ & $\begin{array}{c}\text { Potensi wakaf } \\
\text { uang/tahun }\end{array}$ \\
\hline Rp 500.000 & 4 juta & Rp 5.000,- & Rp 20 milyar & Rp 240 milyar \\
\hline Rp 1 juta - 2 juta & 3 juta & Rp 10.000,- & Rp 30 milyar & Rp 360 milyar \\
\hline Rp 2 juta -5 juta & 2 juta & Rp 50.000,- & Rp 100 milyar & Rp 1,2 triliun \\
\hline$\geq$ Rp 5 juta & 1 juta & Rp 100.000,- & Rp 100 milyar & Rp 1,2 triliun \\
\hline \multicolumn{4}{|c|}{ Total } & Rp 3 triliun \\
\hline
\end{tabular}

Sumber: Mustafa E. Nasution ( 2006)

Secara umum dari total penduduk Indonesia yang berjumlah hampir 230 juta jiwa, jika ada penduduk Muslim yang mampu dan mau berwakaf sebesar minimal Rp. 1.000.000,-/tahun sebanyak 2 persennya atau sejumlah 4,6 juta jiwa, maka akan terkumpul dana wakaf uang per tahun minimal Rp. 4,6 triliun/tahun.

Wakaf merupakan ibadah yang berdimensi ganda, selain untuk menggapai keridhaan serta pahala dari Allah, wakaf merupakan ibadah yang berdimensi sosial. Dalam sejarah Islam, wakaf banyak digunakan untuk kepentingan sosial. Wujud kepentingan sosial tersebut dapat berupa pemberdayaan masyarakat, jaminan sosial, pendidikan, kesehatan, dan lain-lain.

Dalam manajemen modern saat ini, wakaf diintegrasikan dengan berbagai sistem modern yang telah ada, terutama terkait dengan wakaf uang saat ini tengah digencarkan di Indonesia. Berdasarkan UU No. 41 tahun 2004, penerimaan dan pengelolaan wakaf uang dapat diintegrasikan dengan lembaga keuangan syariah. Dalam wakaf uang, wakif tidak boleh langsung menyerahkan mauqüf yang berupa uang kepada nāzir, tetapi harus melalui LKS, yang disebut sebagai LKS Penerima Wakaf Uang (PWU).

Dalam sistem pengelolaan wakaf uang tidak banyak berbeda dengan wakaf tanah atau bangunan, nāzir bertugas untuk menginvestasikan sesuai

${ }^{7}$ Mustafa Edwin Nasution, "Wakaf Tunai dan Sektor Volunteer", dalam Mustafa Edwin Nasution dan Uswatun Hasanah (ed), Wakaf Tunai Inovasi Finansial Islam (Jakarta: PSTTI UI, 2006), 43-44. 
syariah dengan satu syarat: nilai nominal uang yang diinvestasikan tidak boleh berkurang. Sedangkan hasil investasi dialokasikan untuk upah nāzir (maksimal $10 \%$ ) dan kesejahteraan masyarakat (minimal 90\%) ${ }^{8}$. Untuk lebih jelasnya bisa dilihat dalam gambar 1.

Saat ini yang tengah berjalan adalah kerjasama nāzir dengan perbankan syariah. Ini tercermin dari Keputusan Menteri Agama RI No. 92-96 tahun 2008 yang menunjuk lima bank syariah untuk bermitra dengan nāzir dalam soal wakaf uang. Kelima bank tersebut adalah Bank Muamalat Indonesia, Bank Syariah Mandiri, BNI Syariah, DKI Syariah dan Bank Syariah Mega Indonesia. Namun tidak menutup kemungkinan, ke depan pengembangan wakaf uang juga bisa dipadukan dengan instrumen lembaga keuangan syariah non-bank.

Dalam pasal 34 amandemen UUD 1945 dikatakan, "Bahwa negara mengembangkan sistem jaminan sosial bagi seluruh rakyat dan memberdayakan masyarakat yang lemah dan tidak mampu sesuai dengan martabat kemanusiaan". Berdasarkan amandemen UUD 1945 tersebut secara eksplisit bahwa Negara harus mampu memberdayakan masyarakat. Terminologi pemberdayaan adalah membantu masyarakat agar mereka mampu menjadi mandiri dalam mensejahterakan dirinya sendiri. Wakaf uang sebagai suatu gerakan baru dalam dunia perwakafan terutama di Indonesia mampu mengambil peranan yang signifikan dalam merancang program-program pemberdayaan masyarakat. Tugas memberdayakan masyarakat bukanlah tugas pemerintah semata, tetapi merupakan tanggung jawab setiap elemen masyarakat, yang, karenanya, harus turut serta dalam memberdayakan masyarakat. Program pemberdayaan masyarakat dapat dilakukan dengan sistem perwakafan, hal ini sesuai dengan UU No. 41 tahun 2004 tentang wakaf yang telah mengamanatkan Badan Wakaf Indonesia agar mengelola harta benda wakaf yang berskala nasional dan internasional. Sifat utama perwakafan mengharuskan kekal dan abadi pokok hartanya, lalu dikelola dan hasilnya disalurkan sesuai dengan peruntukannya sangat sesuai dan selaras dengan program sistem jaminan sosial atau asuransi. Dalam perwakafan, pihak wakif dapat menentukan peruntukan hasil pengelolaan harta wakaf (mauquf 'alaih).

${ }^{8}$ UU No. 41 tahun 2004, pasal 12. 
Penghimpunan dan penerimaan

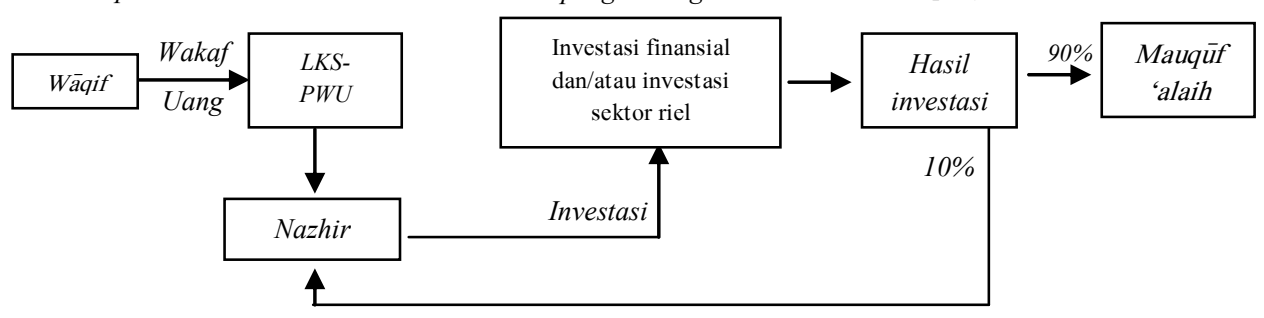

Pendayagunaan dan penyaluran

Gambar 1: Skema Pengelolaan Wakaf Uang ${ }^{9}$

Dalam ketentuan undang-undang terdapat dua model wakaf uang, yaitu wakaf uang untuk jangka waktu tertentu dan wakaf uang untuk selamanya. Wakaf uang jangka waktu tertentu haruslah diinvestasikan ke produk perbankan agar lebih aman dan memudahkan pihak wakaf dalam menerima uangnya kembali pada saat jatuh tempo. Sedangkan wakaf uang untuk selamanya, pihak nāzir memiliki otoritas penuh untuk mengelola dan mengembangkan uang wakaf untuk mencapai tujuan wakafnya. Bila kegiatan investasi menggunakan dana penghimpunan wakaf, maka atas keuntungan bersih usaha hasil investasi ini (yaitu pendapatan kotor dikurangi dengan biaya operasional), akan dibagikan sesuai dengan ketentuan undang-undang wakaf yaitu 90\% keuntungan akan diperuntukkan untuk tujuan wakaf (mauquf 'alaih) dan $10 \%$ untuk penerimaan pengelola atau nāzir.

\section{Peran Wakaf pada Pemberdayaan Masyarakat}

Dalam kehidupan kaum Muslim, Islam sangat menekankan pentingnya keadilan sosial. Dalam beberapa ayat, Allah SWT selalu menekankan betapa pentingnya keadilan ${ }^{10}$, karena keadilan akan membimbing pada ketakwaan (QS Al-Mā'idah: 8), ketakwaan akan membawa pada kesejahteraan (QS Al-A'rāf: 96). Sebaliknya, ketidakadilan akan membawa kesesatan (QS Al-Qașaș: 50) dan akan menjauhkan manusia dari rahmat Tuhan. Intisari ajaran Islam yang terkandung dalam Al-Qur'an mengibarkan panji-panji amanah, egaliter, prinsip emansipatoris dan keadilan sosial.

Para pengelola lembaga wakaf di Indonesia harus peduli dalam mewujudkan masyarakat yang adil dan sejahtera. Lembaga wakaf terutama yang memiliki basis organisasi massa ataupun badan hukum, dapat menjadi

${ }^{9}$ M. Syakir Sula, "Implementasi Wakaf dalam Instrumen Asuransi Syariah."

${ }^{10}$ Abdurrahman Kasdi, "Pemberdayaan Wakaf Produktif Untuk Keadilan Sosial dan Kesejahteraan Umat (Optimalisasi Potensi Wakaf Produktif di Indonesia)," Jurnal Asy-Syir'ah, Vol 44, No. II, (2010), 798. 
salah satu sub-sistem alternatif di masyarakat yang saling bahu-membahu dengan sub-sistem masyarakat lainnya dalam menyelesaikan persoalan bangsa. Wakaf sebagai salah satu pranata keagamaan dalam Islam yang memiliki keterkaitan langsung secara fungsional dengan upaya pemecahan masalahmasalah sosial dan kemanusiaan seperti pengentasan kemiskinan, peningkatan sumber daya manusia dan pemberdayaan masyarakat.

Amandemen Undang-undang Dasar 1945 menyebutkan, "Bahwa setiap orang berhak atas jaminan sosial yang memungkinkan pengembangan dirinya secara utuh sebagai manusia yang bermartabat" (Pasal 28 UUD 1945). Sedangkan dalam pasar 34 dinyatakan, "Bahwa negara mengembangkan sistem jaminan sosial bagi seluruh rakyat dan memberdayakan masyarakat yang lemah dan tidak mampu sesuai dengam martabat kemanusiaan".

Beberapa negara yang menganut negara kesejahteraan (welfare state) selama ini telah memberikan jaminan sosial dalam bentuk bantuan asuransi sosial kepada penduduk negaranya. Dengan adanya jaminan sosial dapat menunjang pembangunan nasional yang berkesinambungan. Apabila negara masih belum mampu membiayai suatu jaminan sosial kepada masyarakatnya, maka harus didukung dengan sub-sistem lain, hal inilah yang menempatkan wakaf sebagai salah satu sub-sistem pendukung negara untuk memberikan jaminan sosial.

Sistem perwakafan dapat dilakukan sebagai alternatif yang mungkin dalam merealisasikan jaminan sosial. Hal ini seiring dengan telah disahkannya UU No. 41 tahun 2004 tentang wakaf, yang telah mengamanatkan kepada Badan Wakaf Indonesia agar mengelola harta benda yang berskala nasional dan internasional. Secara mendasar, perwakafan mengharuskan pokok harta tersebut kekal dan abadi, sehingga dikelola dan hasilnya diperuntukkan bagi program jaminan sosial termasuk bagi pemberdayaan masyarakat.

Dalam ketentuan undang-undang terdapat dua model wakaf uang, yaitu wakaf uang untuk jangka waktu tertentu dan wakaf uang untuk selamanya. ${ }^{11}$ Wakaf uang untuk jangka waktu tertentu haruslah diinvestasikan ke produk perbankan agar lebih aman dan memudahkan pihak wakaf dalam menerima uangnya kembali pada saat jatuh tempo. Sedangkan wakaf uang untuk selamanya, pihak nāzir memiliki wewenang penuh untuk mengelola dan mengembangkan uang wakaf untuk mencapai tujuan program wakaf yang dilakukan.

\footnotetext{
${ }^{11}$ Peraturan Pemerintah Nomor 42 tahun 2006, Pasal 48 ayat 3: Dalam hal LKS-PWU menerima wakaf uang untuk jangka waktu tertentu, maka nāzir hanya dapat melakukan pengelolaan dan pengembangan harta benda wakaf uang pada LKS-PWU dimaksud.
} 
Hasil pengelolaan dana wakaf dapat diperuntukkan bagi pemberdayaan masyarakat, ${ }^{12}$ seperti pemberdayaan pendidikan, kesehatan, sosial ataupun ekonomi. Bentuk pemberdayaan pendidikan misalnya dengan mendirikan sekolah gratis dengan kualitas baik atau bantuan bagi kesejahteraan guru. Sedangkan pemberdayaan masyarakat dapat berupa pemeriksaan kesehatan dan pengobatan gratis bagi masyarakat kurang mampu, bantuan gizi ibu hamil, serta persalinan gratis. Pemberdayaan sosial dapat berupa pelatihan kerja dan kewirausahaan. Pemberdayaan ekonomi berupa bantuan dana bergulir.

\section{Efek Pengganda Wakaf Uang ${ }^{13}$}

Efek pengganda ialah untuk mengukur sejauhmana dampak suatu variabel ekonomi terhadap perekonomian secara keseluruhan. Suatu variabel ekonomi yang baik ialah yang memiliki efek pengganda yang luas dalam perekonomian, misalkan investasi, pajak, dan variabel ekonomi lainnya termasuk zakat dan wakaf dalam sistem ekonomi Islam. Efek pengganda yang baik ialah harus memiliki nilai lebih besar daripada satu. Sehingga apabila variabel tersebut berubah, maka akan dapat dilihat seberapa besar pengaruhnya dalam perekonomian.

Berdasarkan Al-Qur' an surat Al-Baqarah ayat 261,yang artinya:

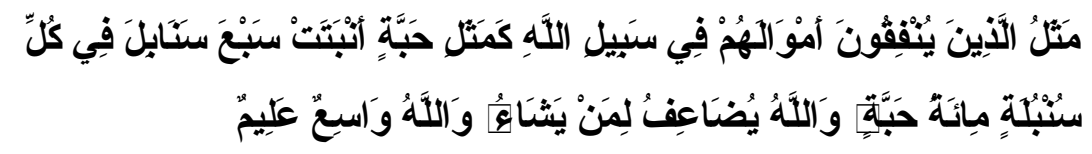

"Perumpamaan (nafkah yang dikeluarkan oleh) orang-orang yang menafkahkan hartanya di jalan Allah adalah serupa dengan sebutir benih yang menumbuhkan tujuh bulir, pada tiap-tiap bulir: seratus biji. Allah melipatgandakan (ganjaran) bagi siapa yang Dia kehendaki. Dan Allah Maha Luas (karunia-Nya) lagi Maha Mengetahui” (QS 2: 261)

Berdasarkan ayat di atas, digambarkan bahwa nafkah yang dikeluarkan di jalan Allah termasuk salah satu di dalamnya adalah wakaf sebagai salah satu instrumen dalam Islam sebagai instrumen pemberdayaan masyarakat ternyata mempunyai efek pengganda dalam perekonomian. Dimana hal ini dinyatakan dengan sebutir benih yang menumbuhkan tujuh bulir dan tiap-tiap bulir seratus

\footnotetext{
${ }^{12}$ M. Nur Rianto Al Arif, "Pemberdayaan Masyarakat Berbasis Wakaf Uang", Jurnal AsySyir'ah, Vol. 44, No. II, 2010, 825.

${ }^{13}$ Bagian ini merupakan pengembangan dari bahasan yang sudah ditulis dalam paper sebelumnya. Lihat M. Nur Rianto Al Arif, "Efek Multiplier Wakaf Uang dan Pengaruhnya terhadap Program Pengentasan Kemiskinan”, Jurnal Asy-Syir'ah, Vol. 46, No. I, 2012, 305-309.
} 
biji, dalam tataran praktis ekonomi efek pengganda ayat ini tidak hanya dari aspek pahala semata namun memiliki dampak ekonomi.

Mekanisme efek pengganda wakaf uang dapat dijelaskan sebagai berikut, yaitu dana wakaf uang yang dikelola oleh nāzir untuk diinvestasikan memberikan hasil, dimana $10 \%$ diberikan kepada nāzir sebagai biaya pengelolaan dan 90\% hasilnya diberikan untuk mauqüf 'alaih. Hasil investasi yang dialokasikan untuk mauqüf 'alaih dapat dibedakan atas dua sektor, yaitu sektor ekonomi dan sektor non ekonomi seperti untuk sosial dan pendidikan. Hasil wakaf uang yang diberikan kepada sektor ekonomi yaitu dalam bentuk dana bergulir. Bantuan tambahan modal yang diberikan dapat digunakan untuk meningkatkan kapasitas produksi, sehingga produksi barang dan jasa dalam perekonomian akan meningkat. Peningkatkan penerimaan negara akan meningkatkan dana pembangunan, peningkatan dana pembangunan ini akan kembali lagi secara tidak langsung kepada peningkatan pendapatan wāqif.

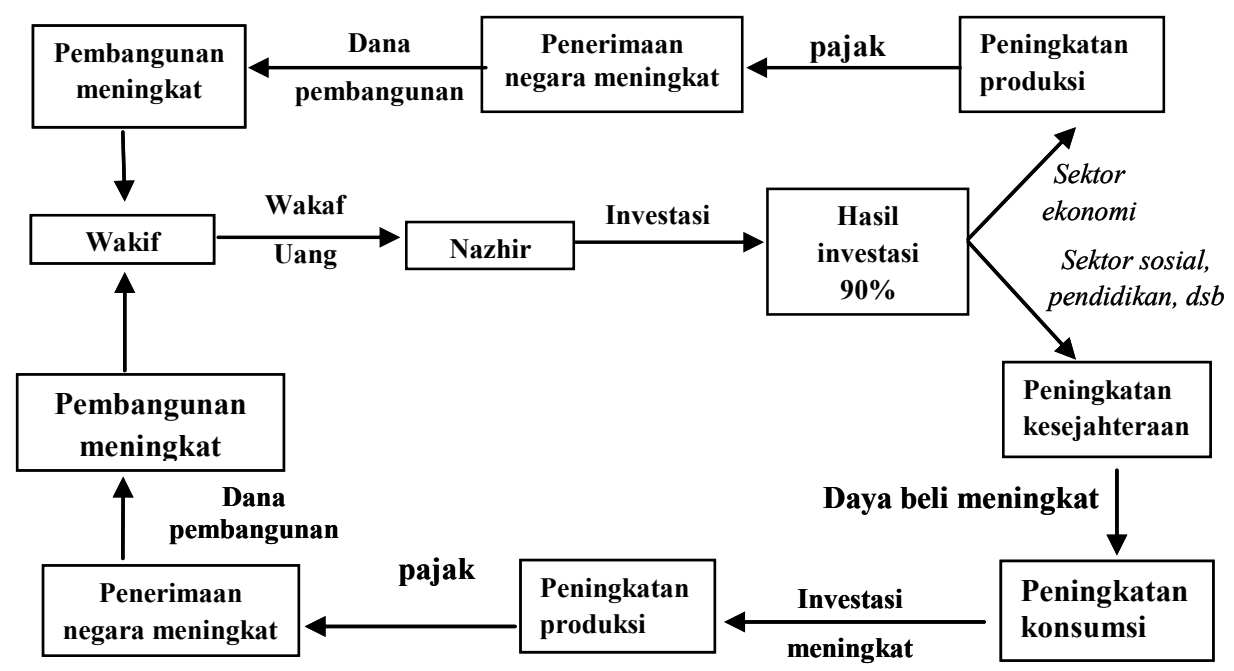

Gambar 2: Efek Pengelolaan Wakaf Uang dalam Perekonomian

Sementara hasil investasi wakaf uang yang dialokasikan untuk sektor non ekonomi baik untuk sektor sosial dan pendidikan bersifat bantuan konsumtif kepada mauqüf 'alaih. Bantuan konsumtif yang diberikan berarti akan meningkatkan daya beli masyarakat yang menerima. Kenaikan daya beli konsumen ini berimplikasi pada peningkatan jumlah konsumsi masyarakat secara langsung, karena saat ini masyarakat memiliki pendapatan yang lebih tinggi untui dibelanjakan. Peningkatan jumlah barang yang diminta oleh konsumen secara langsung akan menggeser permintaan agregat di dalam 
perekonomian. Kenaikan permintaan agregat ini direspon secara positif oleh responden dengan meningkatkan kapasitas produksi, sehingga hal ini berarti akan meningkatkan investasi. Peningkatan kapasitas produksi akan mampu meningkatkan penerimaan Negara, salah satunya penerimaan dalam bentuk pajak. Semakin meningkatnya penerimaan negara maka akan semakin meningkat pula dana pembangunan negara. Hal ini akan memberikan pengaruh secara tidak langsung kepada peningkatan pendapatan wäqif, sehingga terlihat bahwa wakaf uang mampu memberikan pengaruh yang secara langsung dapat meningkatkan pendapatan wāqif maupun pengaruh tidak langsung yang distimulus dengan mekanisme dalam perekonomian.

Berdasarkan mekanisme di atas terlihat bahwa wakaf uang memiliki efek pengganda yang cukup signifikan dalam perekonomian. Hal ini secara langsung dan tidak langsung akan mampu menjadi pengaruh yang signifikan dalam program pengentasan kemiskinan. Semakin besar wakaf uang yang mampu dikelola, maka akan semakin besar pula pengaruh wakaf uang dalam perekonomian terutama dalam mengentaskan kemiskinan.

\section{Penutup}

Saat ini telah terjadi perubahan yang signifikan atas pemahaman dan pemberdayaan harta wakaf di masyarakat, pada awalnya praktek wakaf lebih banyak dikembangkan pada sarana ibadah, sarana pendidikan, sarana kesehatan, dan manfaat sosial lainnya menjadi suatu wakaf produktif termasuk salah satunya dalam bentuk wakaf uang. Wakaf produktif memiliki dua visi sekaligus: menghancurkan struktur-struktur sosial yang timpang dan menyediakan lahan subur untuk mensejahterakan umat Islam.

Dalam ketentuan undang-undang terdapat dua model wakaf uang, yaitu wakaf uang untuk jangka waktu tertentu dan wakaf uang untuk selamanya. Wakaf uang jangka waktu tertentu haruslah diinvestasikan ke produk perbankan agar lebih aman dan memudahkan pihak wakaf dalam menerima uangnya kembali pada saat jatuh tempo. Sedangkan wakaf uang untuk selamanya, pihak nāzir memiliki otoritas penuh untuk mengelola dan mengembangkan uang wakaf untuk mencapai tujuan wakafnya. Bila kegiatan investasi menggunakan dana penghimpunan wakaf, maka atas keuntungan bersih usaha hasil investasi ini (yaitu pendapatan kotor dikurangi dengan biaya operasional), akan dibagikan sesuai dengan ketentuan undang-undang wakaf yaitu 90\% keuntungan akan diperuntukkan untuk tujuan wakaf (mauqüf'alaih) dan $10 \%$ untuk penerimaan pengelola atau nāzir.

Sistem perwakafan dapat dilakukan sebagai alternatif yang mungkin dalam merealisasikan jaminan sosial, hal ini seiring dengan telah disahkannya UU No. 41 tahun 2004 tentang wakaf, yang telah mengamanatkan kepada 
Badan Wakaf Indonesia agar mengelola harta benda yang berskala nasional dan internasional. Secara mendasar, perwakafan mengharuskan pokok harta tersebut kekal dan abadi, sehingga dikelola dan hasilnya diperuntukkan bagi program jaminan sosial termasuk bagi pemberdayaan masyarakat. Hasil pengelolaan dana wakaf dapat diperuntukkan bagi pemberdayaan masyarakat seperti pemberdayaan pendidikan, kesehatan, sosial ataupun ekonomi.

Wakaf uang yang dikelola dapat memberikan efek pengganda dalam perekonomian, baik hasil investasi wakaf uang tersebut diberikan dalam bentuk bantuan sektor ekonomi maupun sektor non ekonomi. Hasil ini secara langsung dan tidak langsung akan mampu memberikan pengaruh signifikan dalam mengentaskan kemiskinan.

\section{Daftar Pustaka}

Al Arif, M. Nur Rianto. "Pemberdayaan Masyarakat Berbasis Wakaf Uang." Jurnal Asy-Syir'ah, Vol. 44, No. II, (2010).

-------. "Efek Multiplier Wakaf Uang dan Pengaruhnya terhadap Program Pengentasan Kemiskinan.” Jurnal Asy-Syir'ah, Vol. 46, No. I, (2012).

-------. "Potensi Wakaf Uang dan Dampaknya Terhadap Perekonomian." Jurnal Dialog, No. 70, Tahun XXXIII, (2010).

-------. Teori Makroekonomi Islam: Konsep, Teori dan Analisis. Bandung: CV Alfabeta, 2010.

Ali, Mohammad Daud. Sistem Ekonomi Islam Zakat dan Wakaf. Jakarta: UI Press, 1988.

Departemen Agama. "Pedoman Pengelolaan Wakaf Tunai." Direktorat Pemberdayaan Wakaf, Jakarta: Dirjen Bimas Islam, 2006.

------. "Strategi Pengembangan Wakaf Tunai di Indonesia." Direktorat Pemberdayaan Wakaf, Jakarta: Dirjen Bimas Islam, 2006.

Faizin, Hamam. "Mengembangkan Wakaf Produktif di Indonesia." Jurnal Dialog, No. 70, Tahun XXXIII, (2010).

Kasdi, Abdurrahman. "Pemberdayaan Wakaf Produktif Untuk Keadilan Sosial dan Kesejahteraan Umat (Optimalisasi Potensi Wakaf Produktif di Indonesia)." Jurnal Asy-Syir'ah, Vol. 44, No. II, (2010).

Proceeding of the Third Harvard University Forum on Islamic Finance. USA: Harvard University, 1999.

Nafis, M. Cholil. "Wakaf Uang Untuk Jaminan Sosial." Jurnal Al-Awqaf, Vol II, No. 2, (2009).

Nasution, Mustafa E. dan Uswatun Hasanah, ed. Wakaf Tunai Inovasi Finansial Islam. Jakarta: PSTTI-UI, 2006.

Rahmawati, Yuke. "Efektivitas Mekanisme Funding Wakaf Uang di Perbankan Syariah.” Jurnal Dialog, No. 70, Tahun XXXIII, (2010). 
Sula, M. Syakir. "Implementasi Wakaf dalam Instrumen Asuransi Syariah." Jurnal Al-Awqaf, Vol II, No. 2, (2009). 